\title{
Analysis of mental workload of electrical power plant operators of control and operation centers
}

\author{
Daiana Martins Vitório ${ }^{\mathrm{a},}{ }^{*}$, Francisco Soares Masculo ${ }^{\mathrm{b}}$ and Miguel O. B. C. Melo ${ }^{\mathrm{c}}$ \\ ${ }^{a b c}$ Production Engineering Post Graduation Program, Federal University of Paraiba, Paraiba, Brazil.
}

\begin{abstract}
Electrical systems can be categorized as critical systems where failure can result in significant financial loss, injury or threats to human life. The operators of the electric power control centers perform an activity in a specialized environment and have to carry it out by mobilizing knowledge and reasoning to which they have adequate training under the terms of the existing rules. To reach this there is a common mental request of personnel involved in these centers due the need to maintain attention, memory and reasoning request. In this sense, this study aims to evaluate the Mental Workload of technical workers of the Control Centers of Electrical Energy. It was undertaken a research on operators control centers of the electricity sector in Northeast Brazil. It was used for systematic observations, followed by interview and application of the instrument National Aeronautics and Space Administration Task Load Index known as NASA-TLX. As a result there will be subsidies for an assessment of mental workload of operators, and a contribution to improving the processes of managing the operation of electric utilities and the quality of workers.
\end{abstract}

Keywords: ergonomics, electric control centers, fatigue, mental workload.

that need to be improved, there are still incidents and accidents, caused mainly caused by fatigue lack of

\section{Introduction}

Currently, the electricity sector is made up of dozens of companies through the agency in many different states and regions, can meet much of the country. The activities performed and services provided by the electric sector are essential to the whole population, which is an important ingredient to the development of a country. One of the biggest challenges companies face is increasingly related to health and welfare of workers especially those directly linked to system operation, in the technical operations.

The activities of the operators of Operation and Control Centers are executed through cognitive tasks that use a complex and specialized. Have as a standard item, the prevention of incidents that disrupt the electrical system, or when it is no longer possible, the process of trying to return to normal, which is called System Recovery. They have to do it by mobilizing knowledge and reasoning for which they received training, which from the point of view of the existing rules are adequate, however, there are some factors concentration or due to inadequate operator / screen / machine / computer.

The operators of these areas are subject to a high degree of uncertainty because the actions of supervisory control and cause there to be a need for an operator to handle various types of data and information, often responding to several requests efficiently and in a timely manner [30].

Thus, it is clear that the development of tasks, requiring more complex development processes relate to the activities of control and diagnosis, and excels in such activities, the operators of Operation and control rooms, where the human error can cause serious risks and losses [30].

The Operation and Control Centers have a basic activity such as monitoring the functioning of the substation, where it is essential to make decisions and process information continuously. For this there is a request of frequent mental technicians involved in these centers because of the need to maintain attention, memory and reasoning request [30].

\footnotetext{
* Cidade Universitária, Pós-Graduação em Engenharia de Produção, João Pessoa - PB, 58.051-970. Brasil, mvdaiana@hotmail.com.
} 
Operation and Control Centers have a basic activity such as monitoring the functioning of the substation, where it is essential to make decisions and process information continuously. For this there is a request of frequent mental technicians involved in these centers because of the need to maintain attention, memory and reasoning request [33].

Among the factors involved in the decisionmaking capacity may be cited [29]:

- Postural requirements: Depending on factors such as existing equipment, lighting, state of continuous attention the task requires, and may lead to worker fatigue and impact on health and productivity of the same company;

- The difficulty in interpreting the data: What can happen either due to environmental conditions such as noise, inadequate lighting and temperature as well as the qualitative and quantitative aspects of the presentation of information?

- Those related to the visual aids and verbal information.

- The duration of activity

The impacts that may arise due to problems in electric power substations can lead to severe disorders resulting from failures in electricity supply and affect also the concessionaire it se. If, which is subject to fines and penalties by ANEEL (National Agency of Electrical Energy). Thus, this fact drives the electricity companies have human resources capable of making decisions quickly and effectively in order to attend the events, both as emergency contingency [29].

Currently the automated equipment performs the greater proportion of mechanical and repetitive activities, while humans perform activities in dynamic contexts, requiring flexibility and quick adaptation to occur effective performance. This adaptation to constantly changing circumstances due to the variability of processes and supervisory function of employees requires complex skills and cognitive abilities. In this scenario, the incorporation of cognitive component analysis of the work became a necessity, so that we can satisfactorily answer the complex skills involved in the operation of modern systems and shift work [4, 5]. Moreover, new technologies allow closer man and technology, while increasing productivity gains.

The aim of this study is to evaluate the mental workload control and operation centers of Electric Power in order to identify the factors that most contribute to the perception of the workload by employees and identify possible situations of overload.

\section{The ergonomics}

Ergonomics, in its most recent definition, appears as a discipline technique that aims to know the "real work activity" aiming at its transformation. Study both the preconditions and consequences of work and the interactions between man, machine and environment during this work [22]. The ergonomic data and knowledge can support and guide the planning and implementation of preventive measures against accidents and occupational diseases, but also reduce the physical discomfort [38] and mental health worker.

The activity is the crossroads of a shuttle between the contents of two coefficients (effectiveness and efficiency) in a social context in which the different partners, which has the same vocation to raise questions to each other, relating to his professional activities, but do not have the same experiences, nor the same opportunities or hierarchical powers to put them into practice [25].

Besides increasing productivity, contributes to a reduction of workload (a) in its psychological component, which determines the experiences of pleasure of the person, (b) in its physical component, minimizing the efforts biomechanical and (c) into its component cognitive, lowering their requirements, such as memory, problem solving, information processing, among others [24].

Mental activities depend on the supply of afferent information and the memory usage for decision making. The ergonomic design appropriate of work a system prevents mental overloads, including the loss or misinterpretation of signals, and facilitates quick and correct actions [21].

How is an interdisciplinary science, also addresses the physiology and psychology of work, anthropometry and society at work? Thus, an ergonomic intervention can result: a direct demand (relative to working conditions) of an indirect claim (linked to job security, manufacturing, the difficulty of recruiting for a given post), or in a planning systematic studies to establish a system to improve quality and increase productivity [33].

\subsection{Cognitive ergonomics}

Cognitive Ergonomics (EC) appears with the practical goals of security, contentment and well-being of workers in their relationship with production systems. Its subject is the operative mobilization of the mental capacities of human beings in the work situation. It seeks this mobilization occurs in the best conditions 
possible and produce the results most relevant to the person dealing with their work and in everyday life [36].

During the procedure of analysis and intervention should be considered the capabilities and limits, both those related to the cognitive and physiological nature of the individual, and we can thus explain the origin of errors and incidents attributed to human error [3].

The character of the work can be directed to the person or company performs. With regard to the personal dimension of the work has been the strategies used by operators to perform your task. This is exactly ergonomic analysis of the object of activity that seeks to know how employees who have individual characteristics are to achieve the goals that are determined by the task entrusted [22].

According to Duarte (2000) recognizes the variability of ergonomics in industry and the need for operators to develop strategies to address and manage this variability, since the plants never work all the time as expected.

Lima e Silva (2000) state that the fact that it is impossible to design automated systems that are reliable without human intervention makes increase the importance of operators to ensure the smooth operation of the facility, being indispensable participation of workers in solving production problems. However, the responsibility placed on operators sometimes leads to trouble the life of them, in studies of continuous processes is common to find reports of operators who say they wake up startled colleagues to call the next turn to his own, to remind them not a problem communicated during the shift change.

The cognitive activity is not directed only to the individual but also the functional system that includes human agents, artifacts and objects in interaction. It is a symmetrical relationship between human agents and artifacts, where the artifact provides a better cognition of human agents allowing them to do more with the artefact than without it. Therefore, artifacts, particularly cognitive artifacts, enable the distribution of access to information, its spread and its treatment [13].

Weill-Fassina (1990) understand the cognitive aspects as being made up of operational modes of action sequences, gestures, probate search and information processing, communications, verbal or graphic IDs incidents or disturbances that characterize the actual task performed by the person. Thus, it is necessary to make records that describe the steps, the temporal development of activities, strategies, verbalizations and the relationships between these va- riables and identify variables that will influence the current situation.

Cognitive Ergonomics has a sub-specialty that studies and analyzes the treatment and handling of information on the computer and the male - in performing a computer task. This particular case is called Ergonomics Human-Computer Interface (HCI) and applies in the context of computerized tasks, where the cognitive processes of the activities are prevalent. IHC is understood as the study of inter-and multidisciplinary character is concerned with computational systems to adapt its user in order to greater satisfaction, safety and productivity.

According to Kroemer and Grandjean (2005) a human-machine system means to be human and the machine keeps a reciprocal relationship in which the human being has a key position, because it is who makes the decisions.

The information highways and their directions are: the display conveys information about the progress of production, the operator needs to realizes this information and understand it and read it correctly. Based on their interpretation and prior knowledge acquired, the human being makes a decision. The next step is to communicate his decision via the machine controls, and parameters can be shown by instruments. The machine then processes what was programmed. The cycle is complete when several important parts of the process, such as temperature or quantity, are shown to the operator [21].

Ergonomics applied to computer systems as is seeks to study the interaction between different system components in order to develop parameters to be inserted in the design of applications that guide users and contribute to the task [3]. There is an axis that focuses on usability, related to the quality analysis system to facilitate their learning and their handling by the user.

Carvalho et al. (2005) in a study of supervisors' decisions during the incident concluded that the micro work is often done through a dynamic redistribution of tasks or functions that involve interactions between individuals that facilitate the decisionmaking.

\subsection{Mental workload}

The concept of workload originally derived from studies of occupational psychology, but was later taken up and developed by ergonomics. Covers the physical effort, the cognitive and psycho affective (emotional) to meet the demands of the task and is divided into physical and psychic pressure. On the 
other hand the physical load of work is mainly due to the technical requirements for processing the work object and can be present both in the workplace and outside it, where it is cited as an example, noise, temperature and lighting. On the other hand, the mental burden relate in a general way, the experiences of stress or psychological decompensation on the organization [11].

The concepts of mental workload and mental load is related to cognitive ergonomics, since this branch deals with the cognitive aspects related to the task through the Cognitive Architecture that involves the description of the different elements that constitute the cognitive system and their relationships. While mental workload refers to the workload related to psychological and cognitive aspects of the task [26, 27].

The association between mental workload and cognitive architecture was proposed by Richard (1990) and can be seen in Figure 1.

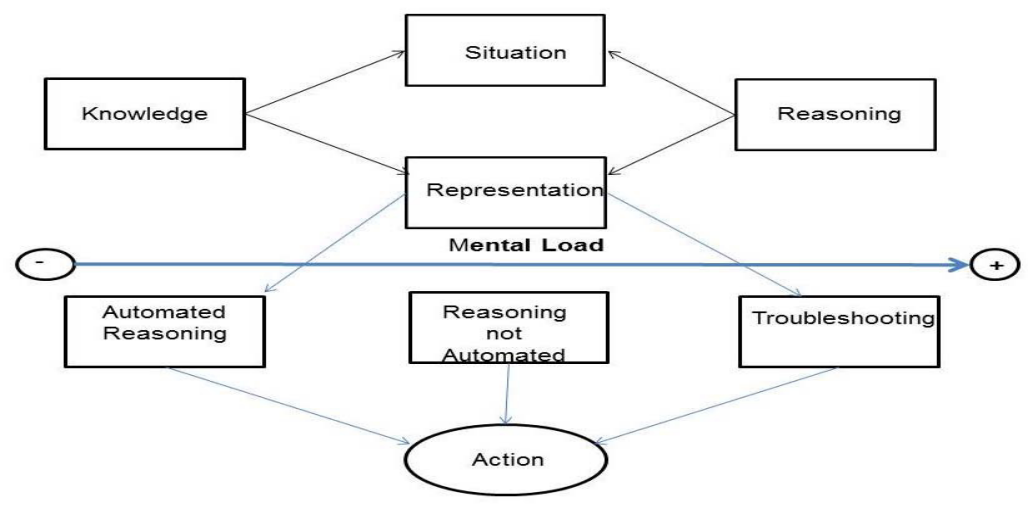

Figure 1

Cognitive architecture associated to mental workload concept

In the model presented is the consideration that automated reasoning has a mental burden lower than those associated with resolving problems. This initial guess can be confirmed or not in a particular work situation.

Rasmussen (1991) proposes a concept of mental workload associated with the cognitive architecture that does not have an ordinance increasing the mental load that can be brought from the architecture itself

In this case, one cannot associate the mental load and a linear distribution associated with increasing cognitive architecture as in the case of Richard (1990), but the overhead is calculated at each step proposed by the architecture, as observed in Figure 2. 


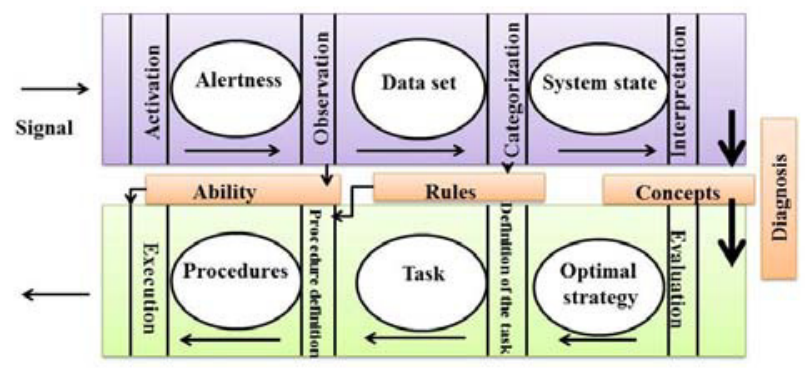

Figure 2

Cognitive Architecture of Rassmussem

Moray (1998, apud CORRÊA, 2003) presents an interesting parallel between the construction of mental models by operators in complex systems and mental workload. In this work he shows that the operator usually divides their work in various models and sub models and states: the effect of levels of modeling is to reduce the mental burden of the operator [13].

What we try to emphasize is that the use of subjective methods for assessing mental load gives researchers a basis for comparison between different moments in performing the same task or between different tasks. From this base, you can make a series of investigations, including bridging the barrier is psychological and organizational aspects.

\section{Brazilian electric sector}

Institutional changes currently underway in the Brazilian electric sector are aimed at establishing a free market in energy, increasing the efficiency of the industry by enabling competition and raise funds for expansion. In this market, like any other, participants and agents seek to improve its strategic position by achieving a competitive advantage over competitors, in order to allow its survival and growth in the system of free competition [12].

The analysis of changes in the actions of agents of the sector, resulting from the recent institutional changes in the electricity sector, therefore, must refer to the factors that determine competitiveness in the segment, to evaluate the standard of competition and competitive strategy that is presumably being adopted by companies.

\subsection{Electric power control center}

The control and operation centers have basic activity functioning surveillance systems, where it is es- sential to make decisions and process information continuously. For this there is a common mental request of personnel involved in these operation centers because of the need to maintain attention, memory and reasoning request [22].

By observing the activities of an operator of the control and operation centers of Electric Energy finds that it performs an intense cognitive activity in a complex, specialized and dangerous. They have as a standard item, the prevention of incidents that disrupt the electrical system, or when it is no longer possible, the process of trying to return to normal. They have to do it by mobilizing knowledge and reasoning for which they received training, which under the terms of the current standards are adequate, however, there are some factors that need to be improved, there are still incidents and accidents, caused mainly caused by fatigue, lack of concentration or due to inadequate operator and computer screen [7].

Electrical systems can be categorized as critical systems - systems where failure can result in significant financial loss, physical harm or threats to human life. In these systems, there is an operator interface that presents a mixed result in misinterpretation and induces errors during the decision-making. It requires, therefore, these systems, among other characteristics of quality: safety, adaptability to different users and levels of experience, and ease of learning and use [24].

Salles (2010) presents and analyzes various aspects of the technicians of the electricity sector and covers aspects of cognitive ergonomics and its contribution in the areas of reasoning, comprehension and memory among others.

The task of the operators are performed by mobilizing knowledge and reasoning for which they received training, which from the point of view of the existing rules are adequate, however, there are some factors that need to be improved, there are still acci- 
dents, incidents caused mainly caused by fatigue or concentration. The complexity of the task can be defined by different factors. Well-Fassina (1990) characterizes the complexity of the tasks of the cognitive point of view.

The task tends to be more complex:

- The greater the number of elements to be treated;

- $\quad$ Require the subject to a capacity assessment and anticipation of the procedures and malfunctions;

- If it requires an individual to a marked capacity for abstraction;

- If your nature is dynamic and uncertain, raising the number of disturbances.

As for the reasoning employed by operators to solve the problems of operation and control, has been studied primarily caused by verbalizations in a situation of simulation and so much more rare, making the operator narrate their activity. However, according to Vidal (2000) there is always an influence of frequency of incidents on the reasoning of the operators, and in this case, a situation that shows familiarity, quickly produces a habitual response, which may not be the most appropriate option. There are sometimes "shortcuts" in arguments, which are explained by operator experience.

According to Abrahão (2000) the activity of an operator continuous process basically consists in obtaining, processing and storing information from different points of different nature and different content. From this, it builds your problem to then act on the functioning of the process. For this action to be effective he must have access to an updated representation (real time) of the functional state of the system. Carvalho et al. (2008) assert that using the approach of human factors in design of control systems in all industries presents many opportunities for improvement with regard to the system's effectiveness, efficiency, reliability and security.

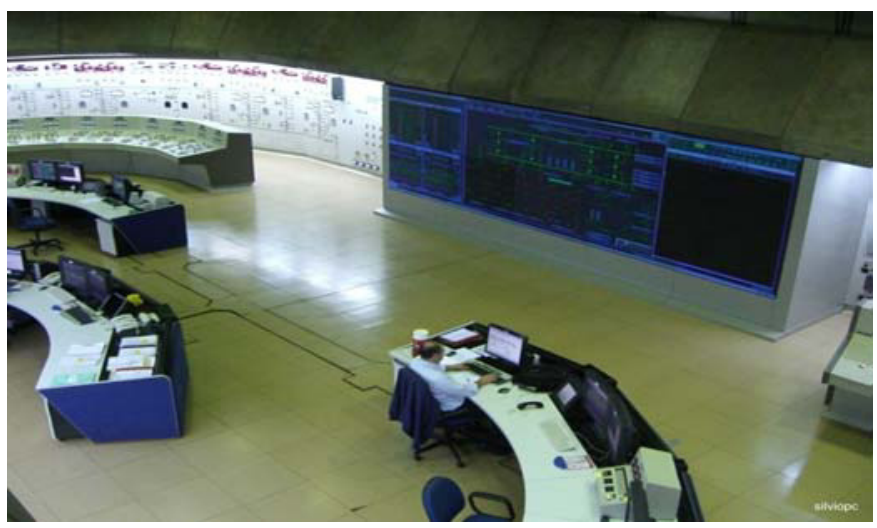

Figure 3

The typical Electric Power control Centers

\section{Methods and models}

This research was a descriptive study, and its results were analyzed quantitatively in substations of electric power in Brazil, comprising 27 operators.

The instrument used was the National Aeronautics and Space Administration Task Load Index known as the NASA-TLX [28], which was developed by the NASA Ames Research Center in 1986, after 3 years of studies involving over 40 laboratories' research and flight simulations. The NASA-TLX method works with physiological indicators associated with subjective methods in situations simulated in the laboratory or in real situations and operational work, taking great advantage of being applicable to various operators and activities without the need of changes in its structure. The NASA-TLX was developed from the concept of mental workload of DIN 33405:198702s predecessor, in accordance with ISO 10075 [30].

It is a multidimensional assessment procedure that gives an overall score of the workload based on a weighted average of the scores obtained in the six factors of NASA-TLX scale. These six factors are as follows: levels of achievement, effort and frustration, which have strong influence from the characteristics of individual operators, and the requirements of mental, physical, and time factors that are determined by the work situation [11]. 
With regard to satisfaction with the performance of the staff, the level of effort with respect to how much one has to work physically and mentally to achieve a good performance, as well as the level of frustration, factors that inhibit the performance of work, such as insecurity, irritation, lack of stimulation, and setbacks are important. On the other hand, the mental requirement involves mental activity needed to complete the work, and the physical requirement corresponds to physical activity required for the performance of work requirement and time on the level of pressure needed to achieve the same (Table 1) [14].

Table 1 - Factors considered in the NASA-TLX Instrument

\begin{tabular}{|c|c|c|}
\hline Factors considered & Low Limit & High Limit \\
\hline Mental Demand & $\begin{array}{l}\text { Tasks considered easy, simple, goals achieved without } \\
\text { difficulties }\end{array}$ & $\begin{array}{l}\text { Tasks difficult, complex, requiring much } \\
\text { mental effort to achieve the goal }\end{array}$ \\
\hline Physical Requirement & Light, slow, easily accomplished tasks & Heavy, quick, strong, and lively tasks \\
\hline Temporal Requirement & $\begin{array}{l}\text { Slow and relaxed pace, with low pressure to the termi- } \\
\text { nation of activities }\end{array}$ & $\begin{array}{l}\text { Fast and furious pace, with lots of pres- } \\
\text { sure for completing the activities }\end{array}$ \\
\hline Level of Effort & $\begin{array}{l}\text { You feel very happy and are praised when it reaches the } \\
\text { goals }\end{array}$ & $\begin{array}{l}\text { You become no satisfied and almost no } \\
\text { one notices your work }\end{array}$ \\
\hline Level of Achievement & $\begin{array}{l}\text { For the task to be performed successfully, surface con- } \\
\text { centration, muscle strength light weight, and simple rea- } \\
\text { soning are required (lack of skills) }\end{array}$ & $\begin{array}{l}\text { Deep concentration, muscle strength, in- } \\
\text { tense, complex reasoning, and great skill are } \\
\text { needed }\end{array}$ \\
\hline Level of Frustration & $\begin{array}{l}\text { You feel safe, happy, and relaxed when you run the } \\
\text { task }\end{array}$ & $\begin{array}{l}\text { You feel insecure, discouraged, angry, } \\
\text { and bothered with the task }\end{array}$ \\
\hline
\end{tabular}

\section{Data analysis}

The overall weighted average ranged from 8.81 to $17.77(=14.36, \mathrm{SD}=4.54)$. In order to obtain an overview of the overall scores given by the weighted sample, descriptive analysis was performed, as mean, standard deviation and quartiles according to Table 2 .

Table 2

Score of the Results of the Weighted Overall Rate (WOR) of the sample

\begin{tabular}{|c|c|c|c|c|c|c|c|}
\hline \multirow[b]{2}{*}{$\begin{array}{l}\text { Weighted Overall Rate (WOR) } \\
\text { Areas }\end{array}$} & \multirow[b]{2}{*}{$\begin{array}{l}\text { Applied Range } \\
\text { (AR) }\end{array}$} & \multirow[b]{2}{*}{$\mathrm{N}$} & \multirow[b]{2}{*}{$\begin{array}{l}\text { Mean Value } \\
\text { (MV) }\end{array}$} & \multicolumn{3}{|c|}{$\begin{array}{l}\text { Distribution points that di- } \\
\text { vide the quadrants }\end{array}$} & \multirow{2}{*}{$\begin{array}{l}\text { Standard Devia- } \\
\text { tion } \\
\text { (SD) }\end{array}$} \\
\hline & & & & $25 \%$ & $50 \%$ & $75 \%$ & \\
\hline Mental Demand & $1-20$ & 27 & 17,77 & 17,00 & 19,00 & 20,00 & 3,77 \\
\hline Physical Requirement & $1-20$ & 27 & 10,25 & 7,00 & 11,00 & 13,00 & 5,36 \\
\hline Temporal Requirement & $1-20$ & 27 & 17,00 & 17,00 & 19,00 & 20,00 & 4,39 \\
\hline Level of Effort & $1-20$ & 27 & 15,88 & 14,00 & 16,00 & 19,00 & 4,04 \\
\hline Level of Achievement & $1-20$ & 27 & 15,74 & 15,00 & 16,001 & 19,001 & 4,46 \\
\hline Level of Frustration & $1-20$ & 27 & 8,81 & 5,00 & 0,00 & 4,00 & 5,21 \\
\hline WOR & $1-20$ & 27 & 14,24 & 12,5 & 16,20 & 18,00 & 4,40 \\
\hline
\end{tabular}

The higher the average Mental Requirement (EM), the more the individual feels that demand in the workplace. The average was 17.77 EM. The distribution of scores by percentile shows that $75 \%$ of the sample have a score to 20.00 . Taking into account that the scale of the domains varies from 10 to 20 , whose mid-point (which represents a point of indifference or neutrality) 19.00 , scoring 19.00 indicates that $75 \%$ of the sample has high scores in EM.

With regard to the physical demands (EF), found that $25 \%$ of the sample has to score 7.00 . Thus, one quarter of the sample has low scores. Half of the sample $(50 \%)$ had scores of up to 11.00 , which equates to a low score on a scale ranging from 1 to 20. The average EF is 10.25 . It is observed that the demand for physical effort is indeed very small, since most of the time the operators are sitting, they stand only in certain situations to monitor the machines or when directed into the courtyard to perform inspections on equipment.

With regard to the Temporal Requirement (ET), is that in general, the average of 17.00 which shows high levels of mental demands. This is confirmed by the distribution by quartile, while $25 \%$ of the sample has to score 17.00 in the scores of temporal requirement. Half of the distribution has to score 19.00 . 
Thus, the sample of operators has high time requirements. The level of effort brings together the physical and mental demands and the study has an average of 15.88. It is observed that $25 \%$ of the sample has scores up to 17.00 , thus, one quarter of the sample has moderate score, $50 \%$ of the sample have scores to 19.00. As mental demands presents high values, while the physical demands, low values, there is a level of effort to moderate score.

The distribution of scores by quartile shows that, with respect to Level of Achievement (NR), 25\% of the sample has a score of 15.00 , while $75 \%$ have a high score of 19.00 . The average of 15.74 shows a high score. It is possible to conclude that the operators are happy when they successfully perform the activities they are intended.

Level of Frustration in the field (NF), 50\% of the sample has a low score of 10.00 and scores of $75 \%$ of the sample is 14.00 . As a result, operators have low values in relation to the level of frustration and in this way they feel safe when they realize their work. This security may be a consequence of routine training that the company does, thus giving subsidies to employees to perform their activities.

In this light, it appears that among the analyzed categories that make up the overall rate the highest weighted average corresponds to Mental Requirement $(\bar{X}=17.77)$, followed by Temporal Requirement $(\bar{X}=17.00)$. The lowest averages relate to Physical Requirements $(\bar{X}=10.25)$ and the frustration level $(\bar{X}=8.81)$.

\section{Conclusions}

- The measurement of the mental requirements average level was high $\mathrm{EM}=17.77$ (range 1.00 to 20.00). The distribution of scores by percentile shows that $75 \%$ of the sample has maximum score to $\mathrm{EM}=20.00$.

-With this method there will be subsidies for an assessment of mental workload and ergonomic aspects of the operators at the Electric Power Control Centers.

- With these data will be a contribution to the operation management of the electric utility company.

\section{References}

[1] Abrahão, J. Ergonomia. Modelo, Métodos e Técnicas. Segundo Congresso Latino-Americano e Sexto Seminário Brasileiro de Ergonomia, 1993.
[2] Abrahão, J. Reestruturação Produtiva e Variabilidade do Trabalho: Uma Abordagem da Ergonomia. Psicologia: Teoria. e Pesquisa, v.16, no.1, Brasília Jan. 2000.

[3] Abrahão, J.; Silvino, A. M. D.; Sarmet, M. M. Ergonomia, cognição e trabalho informatizado. Psicologia: Teoria e Pesquisa. V. 21, n. 2, 2005.

[4] Akerstedt, Torbjorn; Landstrom, Ulf; 1998, Work place countermeasures of night shift fatigue, International Journal of Industrial Ergonomics, Volume 21, Issues 34, March, pp. 167-178.

[5] Baulk, S.D. ; Fletcher, A.; Kandelaars, K.J.; Dawson, D.; Roach, G.D., A field study of sleep and fatigue in a regular rotating 12-h shift system, Applied Ergonomics, Volume 40, Issue 4, July, 2009, pp. 694-698.

[6] Bandeira, F. D. P. M. Análise das alterações propostas para o modelo do setor elétrico brasileiro. Consultoria legislative, agosto, 2003.

[7] Carvalho, P. V.R.; Santos, I. L. D.; Vidal, M. C. R. Nuclear power plant shift supervisor's decision making during microincidents. International Journal of Industrial Ergonomics 35, 2005, 619-644.

[8] Carvalho, E. F; Verboonen, M.; Carvalho,, B.B. Análise Ergonômica do Trabalho na operação de um Simulador de Usina Nuclear.Disponível em: http://www.gpi.ufrj.br/pdfs/artigos Acesso em: 18 jan. 2008.

[9] Carvalho, P. V. R.; Santos, I. L. D.; Gomes, J. O.; Borges, M. R. S.; Guerlain, S. Human factors approach for evaluation and redesign of human-system interfaces of a nuclear power plant simulator. Displays 29, 2008, 273-284.

[10] CCEE, Câmara de Comercialização de Energia Elétrica. $\mathrm{O}$ Setor Elétrico Brasileiro. Disponível em: www.ccee.org.br. Acesso em: 18 de fevereiro de 2011.

[11] CORRÊA, F. 2003, Ergonomics and Work Mental Load, Master Science Dissertation (in Portuguese), Federal University of Santa Catarina, Brazil.

[12] CHESF, Companhia Hidro Elétrica São Francisco. Sistema Chesf. Disponível em: www.chesf.gov.br. Acesso em: 18 de fevereiro de 2011.

[13] Darses, F.; Falzon, P.; Munteguy, C."Paradigmas e modelos para a análise cognitiva das atividades finalizadas". In: Falzon, P. Ergonomia. São Paulo: Blucher, 2007, pp. 155-176.

[14] Diniz, R, Evaluation of physical and mental demands on the surgeon's work in elective procedures. Doctor Thesis in Production Engineering, (in Portuguese), Federal University of Rio Grande do Sul, Brazil, 2003.

[15] Duarte, F. Ergonomia e Projetos. EdLucena, 2000.

[16] ESCELSA, energias do Brasil. História da energia elétrica do Brasil. Disponível em: http://www.edpescelsa.com.br. Acesso em: 19/22011

[17] Ferreira, M. C. Atividade, categoria central na conceituação de trabalho em ergonomia. Alethéia, 2000.

[18] Gomes, A.C.S.; Abarca, C. D. G.; Faria, E. A. S. T. Fernandes, H. H. D. O. O setor elétrico. BNDS, 2002.

[19] Grandjean, E.; Kroemer, Karl. Fitting The Task To The Human, Fifth Edition: A Textbook of Occupational Ergonomics, London: Taylor \& Francis, 1997.

[20] Guerin, F. Compreender o trabalho para transformá-lo: a prática da ergonomia. Editora Blucher, 2001.

[21] Iida, I., 2005, Ergonomics: Project and Production, (in Portuguese), second edition, São Paulo: Blucher.

[22] KU, Chia-Hua; Smith, Michael J. Organisational Factors and Scheduling in Locomotive Engineers and Con- 
ductors: Effects on fatigue, health and social well-being, Applied Ergonomics, 41, January, 2010, pp. 62-71.

[23] Landi, M. Energia elétrica e políticas públicas: a experiência do setor brasileiro no período de 1934 2005, Programa Interunidades de Pós-graduação em Energia (Tese) - São Paulo, 2006.

[24] Lima, F. DE P. A. Ergonomia, ciência do trabalho, ponto de vista do trabalho: a ciência do trabalho numa perspectiva histórica. Revista Ação ergonômica, v. 1, n. 2 , p. $35-46,2001$.

[25] Meijman, T. F, Mental Fatigue and the Efficiency of Information Processing in relation to Work times, International Journal of Industrial Ergonomics, 20, Issue 1, July, 1997, pp. 31-38.

[26] Murata, A; Uetake, A; Takasawa, Y. Evaluation of Mental Fatigue using Feature Parameter Extracted from Event-related Potential, International Journal of Industrial Ergonomics, 35, Issue 8, August, pp 761-770, 2005.

[27] NASA TLX Disponible in http://humansystems.arc.nasa.gov/groups/TLX/comput er.php, 2008.

[28] Neves, T. I. "Estudo da dinâmica do trabalho em Centro do Controle de Operações segundo a abordagem da Gestão do Conhecimento". Dissertação. Itajubá: Universidade Federal de Itajubá, 2007.

[29] Oliveira, A. M. B., 2009, Fatigue Analysis in Operators of the Electrical Substation Control Rooms, Master Dissertation, (in Portuguese), Federal University of Paraiba.

[30] Richard, J. F. Les Activités Mentales. Paris: Armand Polin, 1990.
[31] Sarmet, M. M. Análise ergonômica de tarefas cognitivas complexas mediadas por aparato tecnológico: quem é o tutor na educação à distância? Dissertação de mestrado. Universidade de Brasília, 2003.

[32] Salles, P. F., 2008, The Contribution of Cognitive Ergonomics in the Analysis of Activities of the Operator Control Room. Florianopolis: UFSC, Brazil.

[33] Santos, V.; Zamberlan, M.C. 1992, Ergonomics Design of Control Rooms. (in Portuguese), São Paulo: Fundacion Mapfre.

[34] Sauer, I. Um novo modelo para o setor elétrico brasileiro. Universidade de São Paulo: Programa Interunidades de Pós-Graduação em Energia, $1^{a}$ versão, dezembro, 2002.

[35] Vidal, M. C.; Carvalho, P.V., 2008, Cognitive Ergonomics. (in Portuguese), Rio de Janeiro: Virtual Cientifica.

[36] Vidal, M. C. Ergonomia na Empresa. Útil, Prática e Aplicada. Rio de Janeiro: Virtual Científica, 2001.

[37] Vitório, D. M.; Vieira, S. B. Uma experiência de estágio em psicologia do trabalho: em foco as condições de trabalho em um canteiro de obras em João Pessoa - PB. Em: III Congresso Latino Americano de Ergonomia ABERGO, Rio de Janeiro, RJ, 2010.

[38] Weill-Fassina, A., L'analyse des Sspects Cognitifs du Travail. In: Dadoy. Les Analyses du Travail. Enjeux et Formes. Paris: CEREQ, 1990 